\title{
FISCAL REGIMES IN SPAIN: A MARKOV-SWITCHING APPROACH
}

\author{
Working Paper \\ This version: October 2014 \\ Julián RAMAJO-HERNÁNDEZ \\ Alejandro RICCI-RISQUETE \\ Universidad de Extremadura \\ Departamento de Economía \\ 06006 Badajoz (España, UE) \\ Tel.: +34 924289300 / Fax: +34 924272509 \\ E-mail: ramajo@unex.es ${ }^{\bowtie}$; $\underline{\text { alericci@unex.es }}$ \\ Francisco DE CASTRO \\ European Commission \\ DG EFIN \\ Unit F4 \\ CHAR 12/204 \\ B-1049 Brussels/Belgium \\ Tel.: +32 22980253 \\ E-mail: francisco.de-castro@ec.europa.eu
}

\begin{abstract}
In this paper we study fiscal regime shifts for the Spanish Economy, using a new quarterly dataset of Spanish public finance variables for the period 1986-2012 (De Castro et al., 2014), within a Markov-Switching framework. First, we estimate fiscal policy rules to characterize the behavior of Spanish fiscal policymakers and, second, we estimate a vector autoregressive model to analyze the effects of a shock to the primary deficit-to-GDP ratio on the Spanish economy.

Our results indicate that fiscal policymakers do not seem to track the state of public finances and the evolution of economic activity in both identified regimes; however, they appear to focus on the level of extraordinary expenditure, the responsiveness to which is higher in the first regime than in the second one. Increases in the primary deficit do not succeed in stimulating economic activity; rather, unexpected upsurges in the primary deficit-to-GDP ratio harm economic activity (non-Keynesian effect) in the second regime, which prevails since the ratification of the Maastricht Treaty.
\end{abstract}

Keywords: Fiscal regimes, Fiscal rules, Markov-Switching, VAR, Spain

JEL Classification: E62, E63, F41, H20, H50 


\section{Fiscal Regimes in Spain: a Markov-Switching Approach}

\section{Introduction}

Traditionally, both politicians and economists have agreed on the important role of fiscal policy as an effective tool in issues such as tax collection, income redistribution and macroeconomic stabilization. Regarding the latter objective, how can fiscal policy be employed as a stabilizing instrument in the short run without compromising the sustainability of public finances in the long run? If so, what is the best mode to achieve both of them: discretionary measures or fiscal rules? If found, do the effects of discretionary or regulated fiscal policy measures depend on the expansionary or recessionary state of the economy?

Contrary to what it might seem, the fiscal performance of the EU has been slightly better than that of some advanced economies as the USA or Japan since the beginning of the current international financial and economic crisis. In Table 1, we present some data on that matter in the European Union of Fifteen (EU15), the USA and Japan between 2007 and 2012, which can corroborate our statement. In that period, the annual deficit-to-GDP ratios and the annual debt-to-GDP ratios of the EU15 were lower than those of the USA and Japan. In the same vein, the increase in the debt-to-GDP ratio amounted to around 31 percentage points in the EU15 for that period, which again contrasts favorably with the rise of about 38 percentage points in the USA.

In legislative terms, EMU countries have agreed on mechanisms that introduce some kind of fiscal policy coordination since the early days of the founding of the euro area. In order to avoid that a loose fiscal policy of a Member State imposes constraints on the other ones through the interest rate burden, enforce fiscal discipline within EMU and ensure sound and sustainable public finances, the Stability and Growth Pact (SGP) was approved in 1997 (and later revised and softened). Under the provisions of the SGP, EMU countries must respect two basic criteria: a deficit-to-GDP ratio should be lower than 3 percent and a debt-to-GDP ratio should not exceed 60 percent. Moreover, Member States must develop structural budgetary improvements that ensure a steady and lasting convergence towards their medium-term budgetary objectives (MTOs). The fact that no sanctions have been adopted so far, despite the excessive deficits registered by a number of countries, could have affected the credibility of the EU.

Given these reasons, why is the perceived fiscal vulnerability of the EU higher than that of other advances economies as the USA or Japan? Following Campa (2012), the EU as a whole and each of its Member States are more vulnerable to a sustainability analysis of their public finances because of three distinctive concerns: (1) notable differences in debt levels across the EU15, (2) debt financing and its interest payments in the short term, and (3) poor growth prospects for diluting the debt burden. 
The EU has tried to provide convincing answers to those concerns by several ways. According to the orientation of economic policy measures, the responses to the crisis can be divided in two groups: a first one, which ranges from 2007 to 2009, defined by Keynesian-inspired measures; and a second one, which extends from 2010 on, characterized by a more comprehensive approach. In an attempt to classify the measures contained in that second broad group, three areas can be distinguished: mechanisms to provide financial support to individual EU countries, measures to enhance fiscal policy coordination among EU Member States, provisions aimed to foster fiscal discipline and adopt fiscal consolidation packages, and country-specific measures to boost sustainable growth.

Among the mechanisms to provide financial support to individual EU countries, we should highlight the following ones: two packages of financial assistance to Greece in 2010 and 2011, which consisted of loans, privatization plans and macroeconomic adjustment plans, the European Financial Stabilization Mechanism (EFSM) and the European Financial Stability Facility (EFSF), which were two temporary financial assistance procedures based on guarantees from the EU budget and the euro area Member States respectively, and the European Stability Mechanism (ESM), which is a permanent financial institution designed to provide emergency lending to euro area Member States.

Regarding the measures to enhance fiscal policy coordination among EU Member States, we identify three groups of reforms. A first group consists of reforms on European Legislation, basically a more automatic application of SGP recommendations and sanctions, a new procedure to prevent and correct the upsurge of macroeconomic imbalances in the EU, and a comprehensive yearly cycle of economic and fiscal policy coordination within the EU called the European Semester. Among reforms on national fiscal legislation, the most important is the Fiscal Compact, a part of the Treaty on Stability, Coordination and Governance, which requires EU Member States to enshrine key SGP provisions in national law. Moreover, sizeable fiscal consolidation efforts have been promoted in order to correct excessive deficits, especially in peripheral, more vulnerable economies heavily hit by the crisis. The third group of reforms is country-specific commitments to meet the Europe 2020 Agenda objectives on employment, innovation, education, social inclusion and climate/energy.

With respect to the country-specific measures to boost sustainable growth, we should note that fiscal coordination within the EU remains somewhat limited. At the same time, some EU Member States are making efforts to break the vicious circle between the negative back loops between the perceived solvency of the banking sector and sovereign bonds.

These reforms constitute a first step towards addressing investors' concerns on the fiscal sustainability of the EU as a whole and its Member States. However, as Castañeda (2009) says, the use of fiscal rules is neither a necessary nor a sufficient condition for the development of a fiscal policy that pursues both the sustainability of 
public finances and macroeconomic stability in the medium to long term simultaneously.

The objective of this paper is twofold. On the one hand, we analyze the fiscal behavior of the Spanish economy by estimating fiscal policy rules in which the government reacts to the public debt and the business cycle. Following Afonso and Toffano (2013), we apply Markov-Switching techniques to allow for a shift in the parameters of the fiscal policy rules in order to account for the non-linearity of fiscal policy and its relation to different political preferences. On the other hand, we study the response the Spanish economy to fiscal shocks by estimating a Markov-Switching VAR model that includes macroeconomic, fiscal and financial variables.

Table 1. Fiscal performance in some advanced economies. Deficits and debt as a ratio of GDP. 2007-2012

\begin{tabular}{|c|c|c|c|c|c|c|}
\hline & 2007 & 2008 & 2009 & 2010 & 2011 & 2012 \\
\hline \multicolumn{7}{|c|}{ General Government Overall Balance (\% GDP) } \\
\hline Austria & -1.0 & -1.0 & -4.1 & -4.5 & -2.5 & -2.5 \\
\hline Belgium & -0.1 & -1.1 & -5.6 & -3.9 & -3.9 & -4.0 \\
\hline Denmark & 4.8 & 3.3 & -2.8 & -2.7 & -2.0 & -4.2 \\
\hline Finland & 5.3 & 4.3 & -2.7 & -2.8 & -1.1 & -2.3 \\
\hline France & -2.8 & -3.3 & -7.6 & -7.1 & -5.3 & -4.9 \\
\hline Germany & 0.2 & -0.1 & -3.1 & -4.2 & -0.8 & 0.1 \\
\hline Greece & -6.8 & -9.9 & -15.6 & -10.8 & -9.6 & -6.3 \\
\hline Ireland & 0.1 & -7.3 & -13.8 & -30.5 & -13.1 & -7.6 \\
\hline Italy & -1.6 & -2.7 & -5.4 & -4.3 & -3.7 & -2.9 \\
\hline Netherlands & 0.2 & 0.5 & -5.6 & -5.1 & -4.4 & -4.1 \\
\hline Portugal & -3.2 & -3.7 & -10.2 & -9.9 & -4.4 & -6.4 \\
\hline Spain & 1.9 & -4.5 & -11.2 & -9.7 & -9.6 & -10.8 \\
\hline Sweden & 3.5 & 2.2 & -1.0 & 0.0 & 0.0 & -0.7 \\
\hline United Kingdom & -2.8 & -5.0 & -11.3 & -10.0 & -7.8 & -7.9 \\
\hline EU-15 Average & -0.2 & -2.0 & -7.1 & -7.5 & -4.9 & -4.6 \\
\hline United States & -2.7 & -6.5 & -12.9 & -10.8 & -9.7 & -8.3 \\
\hline Japan & -2.1 & -4.1 & -10.4 & -9.3 & -9.9 & -10.1 \\
\hline \multicolumn{7}{|c|}{ General Government Gross Debt (\% GDP) } \\
\hline Austria & 60.2 & 63.8 & 69.2 & 72.3 & 72.8 & 74.1 \\
\hline Belgium & 84.0 & 89.2 & 95.7 & 95.6 & 97.8 & 99.8 \\
\hline Denmark & 27.1 & 33.4 & 40.7 & 42.7 & 46.4 & 45.6 \\
\hline Finland & 35.2 & 33.9 & 43.5 & 48.7 & 49.2 & 53.6 \\
\hline France & 64.2 & 68.2 & 79.2 & 82.4 & 85.8 & 90.2 \\
\hline Germany & 65.4 & 66.8 & 74.5 & 82.4 & 80.4 & 81.9 \\
\hline Greece & 107.2 & 112.9 & 129.7 & 148.3 & 170.3 & 156.9 \\
\hline Ireland & 24.9 & 44.2 & 64.4 & 91.2 & 104.1 & 117.4 \\
\hline Italy & 103.3 & 106.1 & 116.4 & 119.3 & 120.8 & 127.0 \\
\hline Netherlands & 45.3 & 58.5 & 60.8 & 63.4 & 65.7 & 71.3 \\
\hline Portugal & 68.4 & 71.7 & 83.7 & 94.0 & 108.4 & 123.8 \\
\hline Spain & 36.3 & 40.2 & 54.0 & 61.7 & 70.4 & 85.9 \\
\hline Sweden & 40.2 & 38.8 & 42.6 & 39.4 & 38.6 & 38.3 \\
\hline United Kingdom & 43.7 & 51.9 & 67.1 & 78.5 & 84.3 & 88.8 \\
\hline EU-15 Average & 57.5 & 62.8 & 73.0 & 80.0 & 85.4 & 89.6 \\
\hline United States & 64.4 & 73.3 & 86.3 & 95.2 & 99.4 & 102.7 \\
\hline Japan & 183.0 & 191.8 & 210.2 & 216.0 & 230.3 & 238.0 \\
\hline
\end{tabular}

Note: EU15 averages exclude Luxembourg data.

Sources: IMF Fiscal Monitor, October 2013; Own calculations. 
The rest of the paper is structured as follows. In Section 2, we briefly review the recent literature on fiscal rules that focuses on European countries. In Section 3, we explain the methodology used in this paper, both the analytical and empirical framework and the database. In section 4, we present the results for the different fiscal regimes. Finally, in Section 5, we summarize our findings and conclude.

\section{Literature review}

Since the publication of the famous article "Discretionary versus Policy Rules in Practice" by John Taylor in 1993, where he proposed a simple monetary policy rule which gives interest rates as a function of inflation and output deviations, much has been said about the use of rules in policymaking, especially on the monetary side. Among the advantages of policy rules are their simple specification, their potential to differentiate between discretionary and rule-based policy behavior and their use as a benchmark for policy evaluation (Thams, 2007). Nevertheless, their main disadvantage follows from one of their benefits: their simplicity may not be adequate to deal with complex situations like the current international economic crisis. All in all, policy rules are tools that can guide the action of economic policymakers, as they explicitly link the instruments to the objectives, but the instruments, the objectives and the links can change over time.

On the fiscal side, many advanced countries introduced fiscal rules over the last 25 years, in the form of golden rules, balanced budget rules or deficit and debts targets; the EU's Maastricht criteria and the SGP are usually put as examples. Following Badinger (2009), two basic reasons support the introduction of fiscal rules: on the one hand, to ensure sustainability of fiscal policy through avoiding excessive deficits and unsound policies and, on the other hand, to improve macroeconomic stability by limiting the room for discretionary fiscal policy. Both academics and policymakers acknowledge that the Maastricht criteria together with the SGP led to fiscal consolidations in many EU countries in the nineties and thus served as a discipline device for fiscal authorities.

This move towards "rules rather than authorities" (in the terminology of Friedman, 1948) reflects a fundamental shift in the paradigm of fiscal policy. In this sense, according to the behavior of fiscal authorities, we can distinguish two types of fiscal policies: an "active" (non-Ricardian) fiscal policy and a "passive" (Ricardian) fiscal policy (Leeper, 1991). Fiscal policy is said to be "active" when is does not stabilize public debt, and "passive" when it does stabilize government debt. In this latter case, primary budget balances react to changes in public debt to safeguard fiscal solvency, in a way that future fiscal receipts cover the cost of current outstanding government liabilities.

The applied study of fiscal rules has been methodologically developed from two different perspectives: panel analysis and Markov-Switching regressions. Those papers 
present and test some kind of fiscal policy reaction functions where the primary budget balance reacts not only to the public debt, in order to ensure fiscal sustainability, but also to the output gap, in order to smooth business cycle fluctuations. In this section, we briefly review those recent studies that focus on European countries.

In the first group of studies, Ballabriga and Martinez-Mongay (2005) empirically assess sustainability of public finances in the EU-15 Member States through testing the response of primary surpluses to accumulated debt over the period 1977-2002. They find that sustainability was prevalent in many EU countries before Maastricht, but also that the Maastricht criteria induced the shift towards sustainability in some of them.

Afonso (2008) evaluates the empirical evidence regarding the existence of "passive" (Ricardian) fiscal regimes in EU-15 countries using an annual panel data set for the period 1970-2003. The results highlight that the EU-15 governments have a tendency to use the primary budget surplus to reduce the debt-to-GDP ratio, synonym of a "passive" (Ricardian) fiscal regime throughout the sample period.

Marneffe et al. (2011) analyze the effects of fiscal rules on the fiscal stance by estimating panel-regressions for the 16 euro-area countries for the period 1995-2008. They conclude that an increase in debt gives rise to lower total balances, but also to higher primary balances, which reflects a stabilizing mechanism.

Golinelli and Momigliano (2008) provide an interesting survey on 21 recent empirical papers that analyze the fiscal behavior of EMU countries and try to explain the roots of the differences in their results. They find that differences are driven partly by the choices made in modelling fiscal behavior and in the related notions of fiscal policy cyclicality, but are also affected by data source and vintage.

The second group of studies allows for the endogenous estimation of changes in fiscal policy regimes, which may occur over time, by means of Markov-Switching regressions. Several types of fiscal rules have been estimated: first, a fiscal rule whereby the primary deficit-to-GDP ratio adjusts to stabilize the debt-to-GDP ratio; second, a fiscal rule whereby one fiscal instrument (public expenditure-to-GDP ratio or public receipts-to-GDP ratio) reacts to the other, the government debt-to-GDP ratio and the output gap, and; third, a fiscal rule which combines the two last approaches, i.e. the primary deficit-to-GDP ratio responds to changes in the public debt-to-GDP ratio, the output gap and other variables.

For several EU countries, in the aim of the first branch, Claeys (2006) test the fiscal sustainability of Germany, France, Italy, Great Britain, Spain, the Netherlands and Austria, as well as the United States and Japan, with annual data from the 60s or 70s to 2003. He finds a significant stabilizing reaction to debt, although the model is not able to reject insolvency for Germany, France and Japan. Moreover, he observes that fiscal policy shifts are mainly related to debt. 
Within the second strand of Markov-Switching regression papers, Thams (2007) investigate the relationship between fiscal instruments and public debt for Germany (1970Q1-2003Q4) and Spain (1986Q1-2003Q4). He finds that both Germany and Spain generally exhibit a positive relationship between government revenues and debt, and that both countries changed their policy behavior at the end of the nineties because of rising debt-to-GDP ratios. However, this change in policy behavior differs between the two countries and seems to be non-permanent in the case of Germany.

In terms of the third strand, Afonso and Toffano (2013) assess the existence of fiscal regime shifts in the UK, Germany and Italy, using a new quarterly fiscal data set for the periods 1970Q4-2010Q4, 1979Q4-2010Q3 and 1983Q3-2010Q4 respectively. Their results prove that in the UK fiscal policy tended to be more active for the periods 1992-1996 and as of 2007, in Germany fiscal regimes have been overly passive, supporting more fiscal sustainability throughout the sample period, and in Italy a more passive fiscal behavior is unveiled in the run-up to EMU.

For individual European countries, in the first strand of Markov-Switching regression papers, Claeys (2008) test Sweden's fiscal sustainability using quarterly data from the first quarter of 1970 to the fourth quarter of 2006. He concludes that after the introduction of procedural and numerical rules in response to the severe 1991 fiscal crisis and after the fiscal consolidation in the nineties, those rules did not prevent destabilizing policies over the period 2000-2002.

In the first and second strand of Markov-Switching regression articles, Afonso, Claeys and Sousa (2011) estimate both primary budget deficit and public expenditure and public receipts rules for the case of Portugal utilizing a new dataset of quarterly fiscal series that ranges from the first quarter of 1978 to the fourth quarter of 2007. They find some evidence for the existence of two fiscal regimes: a pre-1988 period, when fiscal policy was active and a-cyclical, and a post-1988 period, when fiscal policy becomes only slightly more passive and pro-cyclical. Nevertheless, this change was not very significant and fiscal policy continued to be unsustainable.

\section{Methodology}

\subsection{The theoretical framework}

Following Kirsanova et al. (2006) and Reade (2011), the theoretical model underlying the specifications of our fiscal rules and our vector autoregressive (VAR) model can be seen as an augmented New Keynesian structural model (see Clarida, Galí and Gertler, 1999) that incorporates not only the usual IS curve, the Phillips curve and the Taylortype monetary policy rule, but also the government budget constraint and the fiscal policy rule. In detail, the theoretical model can be described as follows:

The first equation is an IS curve that takes the form: 


$$
\bar{y}_{t}=\beta_{0}+\beta_{1} \bar{y}_{t-1}+\left(1-\beta_{1}\right) E_{t} \bar{y}_{t+1}-\beta_{2}\left[i_{t}-E_{t} \pi_{t+1}\right]+\beta_{3} b_{t}+\beta_{4} p d_{t}+\varepsilon_{t}^{\bar{y}}
$$

where $\bar{y}_{t}$ is the output gap, $\pi_{t}$ the inflation rate, $i_{t}$ the nominal interest rate, $\left[i_{t}-E_{t} \pi_{t+1}\right]$ the real interest rate, $b_{t}$ the stock of public debt, and $p d_{t}$ the primary (i.e. net of interest payments) deficit defined as public spending minus receipts. The latter two fiscal variables are defined as a ratio of GDP. $\varepsilon_{t}^{\bar{y}}$ is an i.i.d. distributed demand shock. $E_{t}$ is the expectation operator. According to that specification, the output gap is explained by a weighted average of its past and futures values, the contemporary real interest rate, the public debt-to-GDP ratio and the primary deficit-to-GDP ratio.

The second equation is a Phillips curve such as:

$$
\pi_{t}=\alpha_{0}+\alpha_{1} \pi_{t-1}+\left(1-\alpha_{1}\right) E_{t} \pi_{t+1}+\alpha_{2} \bar{y}_{t}+\varepsilon_{t}^{\pi}
$$

where the variables are defined as above and $\varepsilon_{t}^{\pi}$ is an i.i.d. distributed inflation shock. According to that equation, the inflation depends on its lagged and expected values and the output gap. Note that fiscal policy does not affects inflation, contrary to what happens in the IS curve, where monetary and fiscal policies influence the evolution of the output gap.

The third equation refers to debt accumulation:

$$
b_{t}=\left(1+\rho_{t}\right) b_{t-1}+p d_{t}
$$

where the variables are defined as above and $\rho_{t}$ is the rate of return on public debt.

The fourth equation is the Taylor-type monetary policy rule, whose form is:

$$
i_{t}=\phi_{0}+\phi_{1} \pi_{t-1}+\phi_{2} \pi_{t}+\phi_{3} E_{t} \pi_{t+1}+\phi_{4} \bar{y}_{t-1}+\phi_{5} \bar{y}_{t}+\phi_{6} E_{t} \bar{y}_{t+1}+\varepsilon_{t}^{i}
$$

where the nominal interest rate depends on past, present and expectations on the future values of inflation and the output gap. In the words of Leeper (1991), monetary policy is said to be "active" when real interest rates rise in response to higher inflation, that is, when the sensitivity of nominal interest rates to inflation is higher than one $\left(\phi_{1}+\phi_{2}+\phi_{3}>1\right)$; on the contrary, it is "passive" when $\phi_{1}+\phi_{2}+\phi_{3}<1$. According to Svensson (1999), since output is usually considered a good predictor of future inflation, interest rates usually rise in response to a positive output gap $\left(\phi_{4}+\phi_{5}+\phi_{6}>1\right)$.

The fifth equation is a simple fiscal policy rule, which can be expressed as:

$$
p d_{t}=\delta_{0}+\delta_{1} b_{t-1}+\delta_{2} \bar{y}_{t}+\delta_{3} \pi_{t}+\varepsilon_{t}^{p d}
$$

where the primary deficit-to-GDP ratio depends on past debt-to-GDP ratio, the current output gap and inflation. Again, in the words of Leeper (1991), fiscal policy is said to be "active" (non-Ricardian) when it does not stabilize the public debt, that is, when the 
reaction of fiscal policy to debt dynamics $\left(\delta_{1}\right)$ is negative or smaller than the real interest rate, monetary policy will have to reduce interest rates in response to an inflation shock in order to stabilize the public debt; on the contrary, it is "passive" (Ricardian) when the reaction of fiscal policy to debt dynamics $\left(\delta_{1}\right)$ is positive and higher than to the real interest rate.

\subsection{The empirical framework}

\subsubsection{Fiscal rule specification}

Once we have explained the theoretical framework of our policy reaction functions, we continue with the estimation of a fiscal rule for the Spanish economy. Basically, a fiscal rule is an equation that links an instrument of fiscal policymakers to some exogenous variables in order to evaluate and recommend some sort of policy behavior. In this sense, we follow Afonso and Toffano (2013) who were inspired by Bohn (1998, 2005) to estimate a fiscal policy reaction function which is very similar to the one explained above.

The form of the fiscal policy rule can be expressed as:

$$
p d_{t}=\gamma_{0}+\gamma_{1} b_{t-1}+\gamma_{2} \overline{p g}_{t}+\gamma_{3} \bar{y}_{t}+\gamma_{4} \pi_{t}+\gamma_{5} p d_{t-1}+\varepsilon_{t}
$$

where $p d_{t}$ is the nominal primary deficit-to-GDP ratio, $b_{t}$ the nominal debt-to-GDP ratio, $\overline{p g}_{t}$ the primary expenditure (i.e. net of interest payments) to GDP ratio gap defined as the current expenditure minus the trend expenditure, $\bar{y}_{t}$ the output gap calculated as the current output minus the trend output, $\pi_{t}$ the year-on-year inflation, and $\varepsilon_{t}$ a normal mean zero-constant variance error term. For computing the gaps, the trend components are obtained applying the Hodrick-Prescott filter (smoothing parameter equals to 1600) to the $\log$ of real expenditure and the $\log$ of real GDP respectively, whereas inflation is calculated by using the GDP deflator.

The selection of the variables that are contained in our fiscal rule is not trivial. According to Thams (2007), the inclusion of the lagged debt-to-GDP ratio is compulsory for econometric and economic reasons: on the one hand, there would be an endogeneity problem if the current debt-to-GDP ratio were considered and, on the other hand, it would be difficult to empirically detect a contemporaneous reaction of fiscal policy to changes in public debt because of implementation lags. Referring to the optimal taxation theory by Barro (1984), the incorporation of the expenditure gap is based on the fact that temporary rises of government expenditure do not compromise debt stabilization, and the inclusion of the output gap is justified on the grounds that fiscal policy usually follows a countercyclical motive. In this sense, $\gamma_{2}$ would be positive because during exceptional circumstances (e.g. in war times) public expenditure increases and therefore deficit grows, and $\gamma_{3}$ would be negative because in bad economic times (i.e. when output is below trend) automatic stabilizers run and so deficit goes up. 
Finally, as explained in Claeys (2006), the addition of the inflation rate is founded on that fiscal policy can play an inflation-stabilizing role allowing for interaction with monetary policy.

Nevertheless, we should bear in mind that economic time series are not linear, as Hamilton (1989) states in his seminal paper, wherein Markov-Switching models in time series econometrics are introduced. Essentially, nonlinearity is especially pronounced in the asymmetric business cycle, which can be described by a sequence of long but gradual expansions and short but sudden recessions. The way to estimate MarkovSwitching models and its several applications are thoroughly described in Krolzig (1997), and Kim and Nelson (1999). Since fiscal policy is highly influenced by the current phase of the economic cycle and the political sign of the government, we will not only estimate the fixed fiscal policy rule explained in equation (6), but also statedependent ones, whose parameters change endogenously. In detail, the MarkovSwitching fiscal policy rule takes the following form:

$$
\begin{aligned}
p d_{t}= & \gamma_{0}\left(S_{t}^{F}\right)+\gamma_{1}\left(S_{t}^{F}\right) b_{t-1}+\gamma_{2}\left(S_{t}^{F}\right) \overline{p g}_{t}+\gamma_{3}\left(S_{t}^{F}\right) \bar{y}_{t} \\
& +\gamma_{4}\left(S_{t}^{F}\right) \pi_{t}+\gamma_{5}\left(S_{t}^{F}\right) p d_{t-1}+\sigma\left(S_{t}^{F}\right) \varepsilon_{t}
\end{aligned}
$$

where $S_{t}^{F} \in\{1, \ldots, M\}$ denotes the state of fiscal policy at time $t$, which follows a first order Markov chain with transition matrix $P^{F}=\left(p_{i j}\right)$ with elements $p_{i j}=\operatorname{Pr}\left[s_{t}=i, s_{t-1}=j\right]$, for all $i, j \in\{1, \ldots, M\}$, and the other parameters, defined as above, can take different values depending on the fiscal regime of the moment. We should also highlight that the variance of the error term is state dependent. As we have mentioned earlier, fiscal policy is "active" in the sense on Leeper (1991) when the behavior of the fiscal authority targets several objectives other than debt stabilization $\left(\gamma_{1}>0\right)$, and it is "passive" when the fiscal authority aims to stabilize public debt and therefore decreases the primary deficit in response to public debt increases $\left(\gamma_{1}<0\right)$.

Following Gali and Perotti (2003), it would be interesting to disentangle those changes in fiscal policy that are related to the "automatic" influence of business cycle fluctuations (for example, output rises and falls cause changes in public expenditures connected to variations in unemployment benefits, and changes in public receipts linked to modifications in tax revenues) from those associated to "discretionary" measures intentionally implemented by policymakers (for example, "systematic" increases in public consumption or reductions in tax rates when the economy is in a recession, and the opposite in an expansion, and "non-systematic" efforts in exceptional circumstances).

Thus, in order to assess the discretionary comportment of fiscal policymakers only, we re-specify our fiscal rules explained above by employing cyclically-adjusted fiscal variables. Specifically, the "standard" fiscal rule denoted in equation (6) turns into

$$
\overline{p d}_{t}=\gamma_{0}+\gamma_{1} b_{t-1}+\gamma_{2} \overline{p g}_{t}+\gamma_{3} \bar{y}_{t}+\gamma_{4} \pi_{t}+\gamma_{5} \overline{p d}_{t-1}+\varepsilon_{t}
$$


and the Markov-Switching "standard" fiscal policy rule given in equation (7) becomes

$$
\begin{aligned}
\overline{p d}_{t}= & \gamma_{0}\left(S_{t}^{F}\right)+\gamma_{1}\left(S_{t}^{F}\right) b_{t-1}+\gamma_{2}\left(S_{t}^{F}\right) \overline{p g}_{t}+\gamma_{3}\left(S_{t}^{F}\right) \bar{y}_{t} \\
& +\gamma_{4}\left(S_{t}^{F}\right) \pi_{t}+\gamma_{5}\left(S_{t}^{F}\right) \overline{p d}_{t-1}+\sigma\left(S_{t}^{F}\right) \varepsilon_{t}
\end{aligned}
$$

where $\overline{p d}_{t}$ is the cyclically-adjusted primary deficit-to-GDP ratio, $b_{t}$ the debt-to-GDP ratio, $\overline{p g}_{t}$ the primary expenditure-to-GDP ratio gap, and $\bar{y}_{t}$ the output gap. The rest of the variables are defined as above. For calculating every variable in gap terms, we subtract the trend component obtained by applying the Hodrick-Prescott filter (smoothing parameter equals to 1600) from the log of the current value.

\subsubsection{Markov-Switching VAR specification}

The VAR model that we consider as a basic empirical specification can be seen as the reduced form of a standard structural macroeconomic model or, more generally, as an approximation to the conditional solution (without the restrictions imposed by the theory) of a dynamic stochastic general equilibrium (DSGE) model like the augmented New Keynesian structural model described above. Since the behavior of agents is not constant over time and is affected by the prevailing economic environment, the usual VAR representation is replaced by a Markov-Switching VAR model (MS-VAR) whose more general form is as follows:

$$
\mathbf{X}_{t}=a_{0}\left(S_{t}^{F}\right)+A_{1}\left(S_{t}^{F}\right) \mathbf{X}_{t-1}+\ldots+A_{p}\left(S_{t}^{F}\right) \mathbf{X}_{t-p}+a_{p+1}\left(S_{t}^{F}\right) b_{t-1}+\Sigma\left(S_{t}^{F}\right)^{1 / 2} \boldsymbol{\varepsilon}_{t}
$$

where $\mathbf{X}_{t}=\left(\bar{y}_{t}, \pi_{t}, \overline{p d}_{t}, i_{t}\right)$ is a vector of endogenous variables, $a_{0}$ and $a_{p+1}$ are vectors of parameters, $A_{s}$ are matrices of coefficients associated to lagged endogenous variables, $p$ is the lag number of endogenous variables, and $\boldsymbol{\varepsilon}_{t} \approx N\left(\mathbf{0}, \mathbf{I}_{4}\right)$ is the vector of normally distributed errors. Regarding the variables, the endogenous ones are the output gap $\left(\bar{y}_{t}\right)$, the year-on-year inflation rate $\left(\pi_{t}\right)$, the cyclically-adjusted nominal primary deficit-to-GDP ratio $\left(\overline{p d}_{t}\right)$, and the nominal interest rate $\left(i_{t}\right)$, and the predetermined one is the debt-to-GDP ratio $\left(b_{t}\right)$.

Matrices of coefficients and the variance-covariance matrix may switch between the $M$ regimes and, as we said before, $S_{t}^{F}$ denotes the state of fiscal policy at time $t$, $S_{t}^{F} \in\{1, \ldots, M\}$, which follows a first order Markov chain with transition matrix $P^{F}$ with elements $p_{i j}=\operatorname{Pr}\left[s_{t}=i, s_{t-1}=j\right]$. Then, the proposed specification is based on the very general assumption that all the parameters of the VAR model vary according to the state of the economy controlled by the unobserved variable $S_{t}^{F}$.

\subsection{The database}

In this sub-section we briefly explain the database employed in the estimation of the fiscal rules and the fiscal MS-VAR for Spain. Contrary to previous studies, we use a 
new quarterly dataset of Spanish public finance variables fit for economic analysis (see De Castro et al., 2014). The sample period ranges from the first quarter of 1986 to the fourth quarter of 2012 and so includes some facts that are very important for the analysis of the behavior of fiscal policy in Spain: (a) the accession of the country into the European Economic Community in 1986, (b) the construction of its welfare state in the second half of the eighties, (c) the entry into force of the Treaty on European Union (the "Maastricht Treaty") in November 1993, which created the Economic and Monetary Union (EMU) and forced Member States to respect financial and budgetary discipline, (d) the Spanish economic crisis of 1993-1994, (e) the adoption of the Stability and Growth Pact (SGP) in 1997, which constrains Member States to apply sound budgetary policies (basically, a deficit-to-GDP ratio below 3 per cent and a debtto-GDP ratio below 60 per cent) from the time they enter the third stage of EMU (1 January 1999 for Spain), (f) the international financial and economic crisis, whose beginning dated back to the bankruptcy of one of the largest global financial services firms Lehman Brothers in September 2008, and the burst of the housing bubble in Spain, whose climax was marked by the collapse of the country's leading real estate company Martinsa-Fadesa in July 2008, and (g) the intensification of the sovereign debt crisis in the euro area since May 2010.

As Afonso and Toffano (2013) stated, "the choice of using quarterly data is given by the fact that, even if the budget is set annually, infra-annual discretionary adjustments are commonplace in the implementation of fiscal policy".
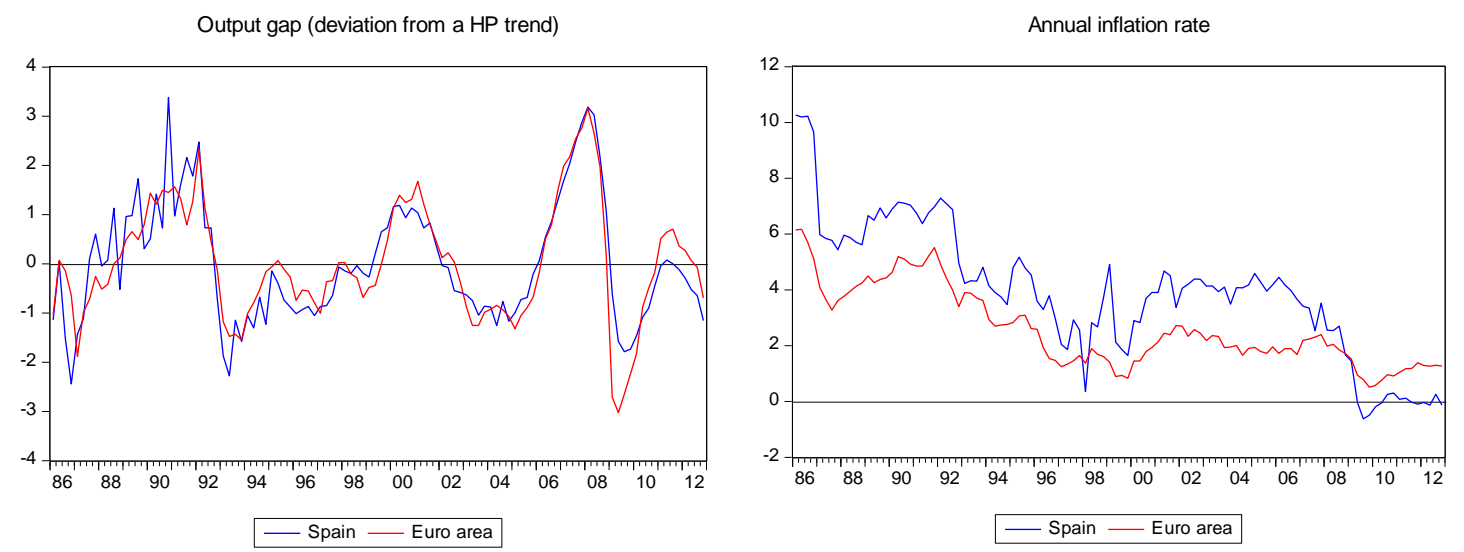

Figure 1. Output gap and inflation rate. Spain vs. the euro area. 1986Q1-2012Q4 Note: All variables are expressed in percentage terms.

Source: Own calculations based on De Castro et al. (2014) and Paredes et al. (2014) databases.

Figure 1 shows the Spanish output gap and the year-on-year inflation rate for the analyzed period. For completeness, we also depict the euro area counterparts, calculated from Paredes et al. (2014) euro area quarterly fiscal database. Note that the estimation of the output gap offers information about the evolution of the economic activity that can be different from the analysis of the economic cycles. Roughly speaking, the country grew above trend from the third quarter of 1987 to the third quarter of 1991, from the second quarter of 1999 to the fourth quarter of 2001 and from the first quarter of 2004 to 2007, growing below trend over the remaining period. Regarding inflation, 
this indicator has essentially decreased thorough the sample period, from two-digit values in the mid-eighties to around zero in the most recent period.
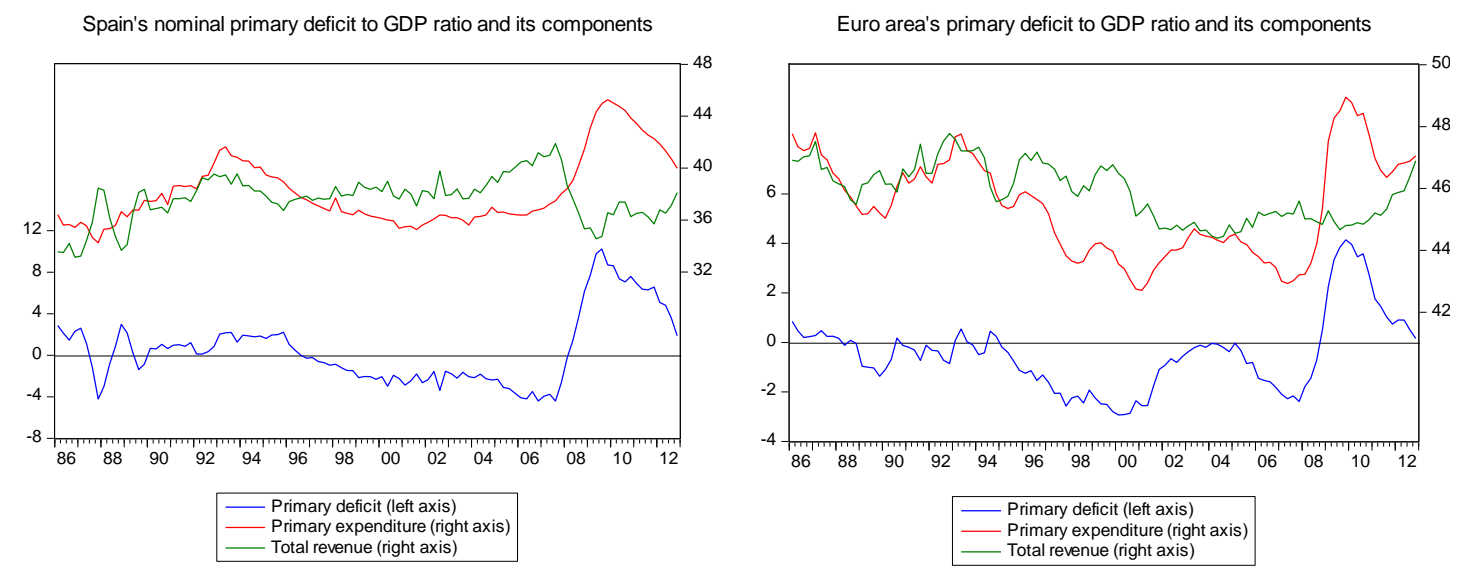

Nominal General Government debt to (annual) GDP ratio

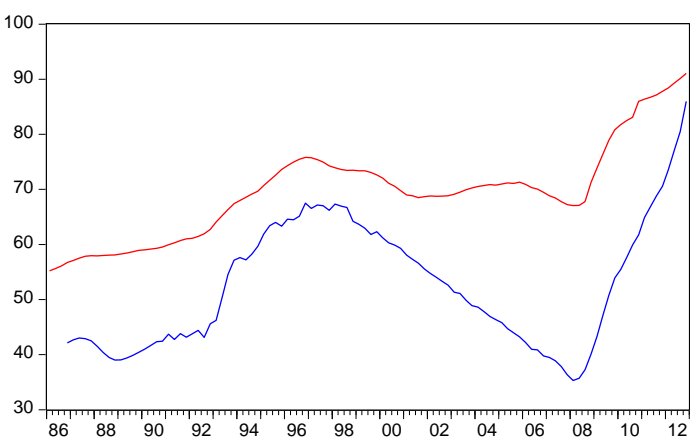

Primary expenditure gap (deviation from a HP trend)

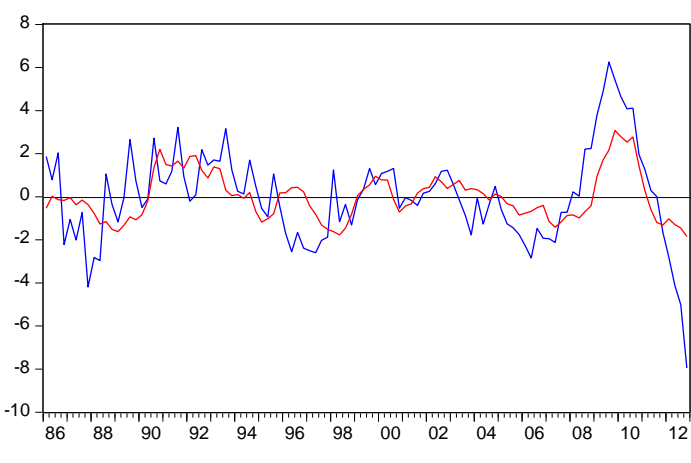

- Spain —- Euro area

- Spain — Euro area

Figure 2. Primary deficit-to-GDP ratio and its components, debt-to-GDP ratio and primary expenditure gap. Spain vs. the euro area. 1986:Q1-2012:Q4

Note: All variables are expressed in percentage terms.

Source: Own calculations based on De Castro et al. (2014) and Paredes et al. (2014) databases.

In Figure 2 we present the Spanish primary deficit-to-GDP ratio, the public debtto-GDP ratio and the primary expenditure gap for the period under scrutiny. For completeness, we also graph the corresponding euro area counterparts, computing from Paredes et al. (2014) euro area quarterly fiscal database. Spain registered a primary surplus in three periods only: first, from the third quarter of 1987 to the second quarter of 1988; second, in the third and fourth quarters of 1989; and, third, from the fourth quarter of 1996 to the first quarter of 2008. That third phase of primary surplus to GDP ratio was accompanied by a reduction of the debt-to-GDP ratio, as we can see from the graph. Both facts are related to the commitment of the Spanish government to meet the convergence criteria set out in the Maastricht Treaty to regulate access to the Third Stage of EMU. However, proper fiscal consolidation does not apply to the whole 19962007 period. While expenditure retrenchment took place in the second half of the nineties, the reduction in the public deficit achieved thereafter was mainly due to buoyant government receipts linked to a large extent to the housing boom.

A somewhat similar picture emerges for the euro area as a whole. Primary surpluses are registered between 1988 and 1993 and from 1995 till the outbreak of the 
Great Recession in 2008. However, while the Maastricht criteria might have been instrumental to promote greater fiscal discipline, it also seems that positive fiscal outcomes are mainly the result of good economic times, rather than structural improvements in fiscal discipline. In this regard, contrary to what was observed in Spain, only limited reductions in the public debt ratio were observed in the euro area between 2001 and 2008.

\section{Results}

\subsection{Fiscal rule results}

\subsubsection{Standard fiscal rule results}

In this subsection we present the outcomes related to the estimation of the "standard" fiscal rules based on equations (6) and (7). We should highlight that these specifications capture not only the discretionary responses, but also the automatic stabilizers' responses to the business cycle or inflation.

Table 2. Standard fiscal policy rules for Spain

\begin{tabular}{|c|c|c|c|}
\hline & \multirow{2}{*}{$\begin{array}{c}\text { Fixed } \\
\text { fiscal rule }\end{array}$} & \multicolumn{2}{|c|}{ Markov-Switching fiscal rule } \\
\hline & & Regime 1 & Regime 2 \\
\hline Constant & $\begin{array}{c}2.0208 * * * \\
(0.7265)\end{array}$ & $\begin{array}{c}0.0434 \\
(0.5970)\end{array}$ & $\begin{array}{c}13.8128 * * * \\
(3.0296)\end{array}$ \\
\hline Lagged (debt/GDP) & $\begin{array}{c}-0.0278 * * \\
(0.0114)\end{array}$ & $\begin{array}{l}-0.0027 \\
(0.0087)\end{array}$ & $\begin{array}{c}-0.2582 * * * \\
(0.0622)\end{array}$ \\
\hline (expenditure/GDP) gap & $\begin{array}{c}0.3467 * * * \\
(0.1310)\end{array}$ & $\begin{array}{c}0.3373 * * * \\
(0.1010)\end{array}$ & $\begin{array}{c}1.3931 * * * \\
(0.4563)\end{array}$ \\
\hline GDP gap & $\begin{array}{c}0.1653 \\
(0.1041)\end{array}$ & $\begin{array}{c}0.0620 \\
(0.0691)\end{array}$ & $\begin{array}{l}-0.1683 \\
(0.3221)\end{array}$ \\
\hline Inflation rate & $\begin{array}{c}-0.1417 * * \\
(0.0569)\end{array}$ & $\begin{array}{c}0.0051 \\
(0.0469)\end{array}$ & $\begin{array}{c}-0.4430 * * * \\
(0.1543)\end{array}$ \\
\hline Lagged (deficit/GDP) & $\begin{array}{c}0.9010 * * * \\
(0.0348)\end{array}$ & $\begin{array}{c}0.9501 * * * \\
(0.0246)\end{array}$ & $\begin{array}{c}0.4228 * * * \\
(0.1066)\end{array}$ \\
\hline $\log ($ sigma $)$ & 一 & $\begin{array}{c}-0.7638 * * * \\
(0.0948)\end{array}$ & $\begin{array}{l}-0.0742 \\
(0.1482)\end{array}$ \\
\hline Transition probabilities & 一 & $\begin{array}{l}\mathrm{P}(1 \mid 1)=0.9625 \\
\mathrm{P}(2 \mid 1)=0.0375\end{array}$ & $\begin{array}{l}\mathrm{P}(1 \mid 2)=0.0919 \\
\mathrm{P}(2 \mid 2)=0.9081\end{array}$ \\
\hline Expected duration (Q) & - & 26.6969 & 10.8754 \\
\hline Log likelihood & -135.0561 & \multicolumn{2}{|c|}{-103.2588} \\
\hline Akaike info criterion & 2.7126 & \multicolumn{2}{|c|}{2.2934} \\
\hline Schwarz criterion & 2.8652 & \multicolumn{2}{|c|}{2.7003} \\
\hline Hannan-Quinn criter. & 2.7744 & \multicolumn{2}{|c|}{2.4583} \\
\hline
\end{tabular}

Notes: The dependent variable is the primary deficit-to-GDP ratio. Standard errors in brackets. Q-Quarters. *,**,***, indicates statistical significance at a 10\%, 5\%, and $1 \%$ level.

Source: Own calculations based on De Castro et al. (2014) database.

We report the Ordinary Least Squares estimation results for the fiscal rule denoted in equation (6) for the Spanish primary deficit-to-GDP ratio in the left side of Table 2. All coefficients are statistically significant, except the parameter associated to the output gap. We observe that the coefficient estimate on lagged debt is negative and statistically significant. Thus, fiscal policy seems to be "passive", suggesting that past debt-to-GDP ratio increases lead to lower primary deficits. As we expected, the primary 
deficit-to-GDP ratio responds positively to the expenditure gap. Moreover, fiscal policy is "acyclical", since the parameter related to output gap is not statistically different from zero. Finally, the coefficient estimate on the inflation rate is negative, implying that higher inflation helps reduce primary deficits.

Next we explain the estimation results associated to the Markov-Switching fiscal policy rule, with two regimes (constant transition probabilities), detailed in equation (7) for the Spanish economy. The filtered probabilities of each regime are plotted in Figure 3 . We observe that regime 1 predominates throughout the sample, except in the period that spreads from 1987:Q2 to 1990:Q3, from 2002:Q3 to 2003:Q3, and from 2007:Q4 to 2010:Q2, when the Spanish government made extraordinary expenditure on grounds of exceptional economic circumstances. In Figure 3 we also show the residual, actual and fitted primary deficit-to-GDP ratio of the Spanish economy. Our fiscal rule denoted in equation (7) seems to adjust the data fairly well.

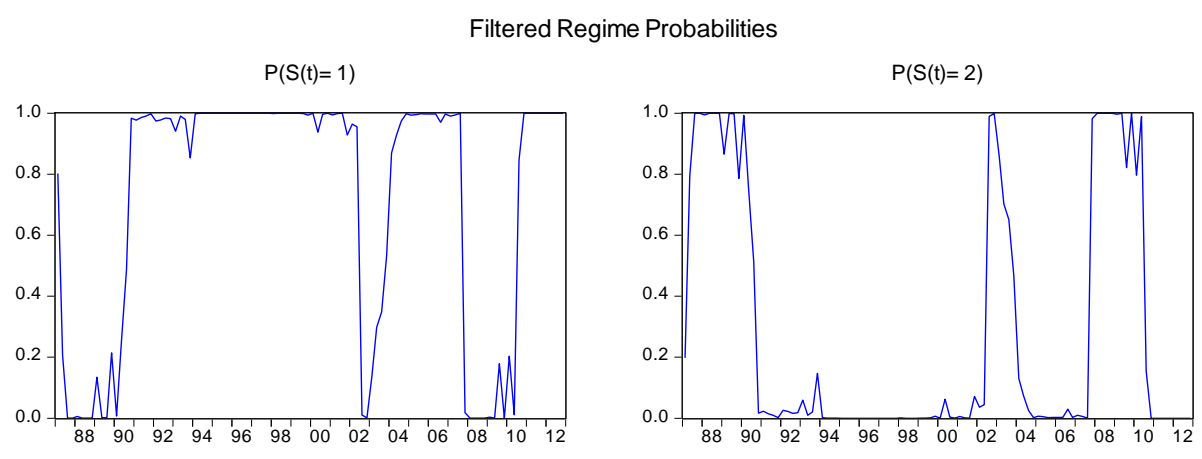

Residual, actual and fitted primary deficit to GDP ratio. Spain. 1986:Q1-2012:Q4

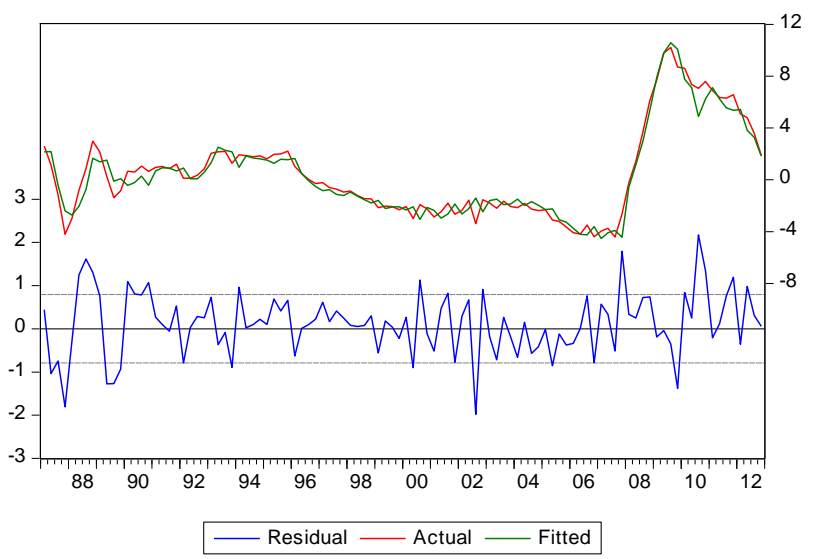

Figure 3. Fiscal regimes (constant transition probabilities) for Spain, 1986:Q1-2012:Q4 Source: Own calculations based on De Castro et al. (2014) database.

The probability that regime 1 is followed by regime 1 is 0.9625 , and the probability that regime 2 is followed by regime 2 is 0.9081 ; therefore both regimes are very persistent as we can see at the bottom right of Table 2. Additionally, the expected duration of regime 1 is higher than that of regime 2. Specifically, regime 1 would last around 27 quarters, whereas regime 2 would prevail for around 11 quarters.

We also show in the right side of Table 2 the Maximum Likelihood estimation results of the Markov-Switching model with two regimes (and constant transition 
probabilities) for the fiscal reaction function specified in equation (7) for the Spanish primary deficit-to-GDP ratio. ${ }^{1}$ We observe that all parameters are statistically significant, except the constant and the parameters related to lagged debt, the output gap and the inflation rate in regime 1 and the coefficient associated to the output gap in regime 2. Fiscal policy seems to be "passive" in regime 2, as the primary deficit-toGDP ratio decreases in response to higher lagged debt. By contrast, although this coefficient is also negative in regime 1 , such effect is not statistically significant. Hence, fiscal policy would be neither active nor passive in this regime.

In addition, our results denote "acyclicality" vis-à-vis the business cycle as proxied by the output gap in both regimes. However, the responses of the primary deficit-to-GDP ratio to primary expenditure gap changes are slightly different. Specifically, although the expenditure gap pushes up the primary deficit in both regimes, this channel is stronger in regime 2 . In turn, fiscal developments improve with price rises in regime 2 . In both regimes, the coefficient estimate of the lagged primary deficit-to-GDP ratio is positive and significant, which implies that this variable shows a high degree of persistence.

To sum up, we can distinguish the existence of two fiscal regimes in Spain: regime 1, which spans between the end of 1990 and the middle of 2002, between the end of 2003 and around the middle of 2007 and from the third quarter of 2010 onwards, characterized by a neither active nor passive and acyclical fiscal policy, and regime 2 , which prevails in the remaining quarters, defined by a passive and acyclical fiscal policy. $^{2}$

For the sake of comparison, in Table 3 we present the combined estimation results of the Markov-Switching fiscal policy rules, with two regimes (constant transition probabilities), specified in equation (7) for Spain and the euro area. From that table, we can differentiate two regimes for the euro area: regime 1, which extends from 1986 to the beginnings of 2008, and regime 2, which covers from the second quarter of 2008 onwards. Both regimes can be described by a neither active nor passive and acyclical fiscal policy; however, extraordinary expenditure is higher in regime 2. Comparing these euro-area results with those of Spain explained above, the time paths of fiscal regimes in Spain and the euro area are not synchronized, Spanish fiscal policymakers are sometimes concerned about debt stabilization because regime 2 is

\footnotetext{
${ }^{1}$ Preliminary analysis indicates that a fiscal rule with three regimes was difficult to estimate with a number of local roots exhibiting coefficient singularity.

${ }^{2}$ Following the suggestion of Diebold, Lee, and Weinbach (1994), and Filardo (1994), who argue that the probability of switching from one regime to the other cannot depend on the behavior of underlying economic fundamentals, but the transition probabilities can and should vary with fundamentals, we estimate the Markov-Switching two-regime fiscal policy rule denoted in equation (7), using variabledependent transition probabilities for the case of Spain. The results are very close to those reported in the main text for constant transition probabilities.
} 
"passive", and extraordinary expenditure is somewhat higher in Spain (especially in regime 2$)^{3}$

Table 3. Markov-Switching standard fiscal policy rules for Spain and the euro area

\begin{tabular}{|c|c|c|c|c|}
\hline & \multicolumn{2}{|c|}{ Spain (see Table 2) } & \multicolumn{2}{|c|}{ Euro area } \\
\hline & Regime 1 & Regime 2 & Regime 1 & Regime 2 \\
\hline Constant & $\begin{array}{c}0.0434 \\
(0.5970)\end{array}$ & $\begin{array}{c}13.8128 * * * \\
(3.0296)\end{array}$ & $\begin{array}{c}0.3912 \\
(1.1575)\end{array}$ & $\begin{array}{c}0.8660 \\
(1.8072)\end{array}$ \\
\hline $\begin{array}{l}\text { Lagged } \\
\text { (debt/GDP) }\end{array}$ & $\begin{array}{l}-0.0027 \\
(0.0087)\end{array}$ & $\begin{array}{c}-0.2582 * * * \\
(0.0622)\end{array}$ & $\begin{array}{l}-0.0133 \\
(0.0147)\end{array}$ & $\begin{array}{l}-0.0092 \\
(0.0190)\end{array}$ \\
\hline $\begin{array}{l}\text { (expenditure/GDP) } \\
\text { gap }\end{array}$ & $\begin{array}{c}0.3373 * * * \\
(0.1010)\end{array}$ & $\begin{array}{c}1.3931 * * * \\
(0.4563)\end{array}$ & $\begin{array}{c}0.2370 * * * \\
(0.0872)\end{array}$ & $\begin{array}{c}0.5241 * * \\
(0.2584)\end{array}$ \\
\hline GDP gap & $\begin{array}{c}0.0620 \\
(0.0691)\end{array}$ & $\begin{array}{l}-0.1683 \\
(0.3221)\end{array}$ & $\begin{array}{l}-0.0400 \\
(0.0602)\end{array}$ & $\begin{array}{l}-0.1098 \\
(0.1257)\end{array}$ \\
\hline Inflation rate & $\begin{array}{c}0.0051 \\
(0.0469)\end{array}$ & $\begin{array}{c}-0.4430 * * * \\
(0.1543)\end{array}$ & $\begin{array}{c}0.0821 \\
(0.0717)\end{array}$ & $\begin{array}{c}0.3698 \\
(0.5609)\end{array}$ \\
\hline $\begin{array}{l}\text { Lagged } \\
\text { (deficit/GDP) }\end{array}$ & $\begin{array}{c}0.9501 * * * \\
(0.0246)\end{array}$ & $\begin{array}{c}0.4228 * * * \\
(0.1066)\end{array}$ & $\begin{array}{c}0.7326 * * * \\
(0.0628)\end{array}$ & $\begin{array}{l}0.5813 * * * \\
(0.1461)\end{array}$ \\
\hline $\log (\operatorname{sigma})$ & $\begin{array}{c}-0.7638 * * * \\
(0.0948)\end{array}$ & $\begin{array}{l}-0.0742 \\
(0.1482)\end{array}$ & $\begin{array}{c}-1.2117 * * * \\
(0.0819)\end{array}$ & $\begin{array}{c}-1.6058 * * * \\
(0.1724)\end{array}$ \\
\hline $\begin{array}{l}\text { Transition } \\
\text { probabilities }\end{array}$ & $\begin{array}{l}\mathrm{P}(1 \mid 1)=0.9625 \\
\mathrm{P}(2 \mid 1)=0.0375\end{array}$ & $\begin{array}{l}\mathrm{P}(1 \mid 2)=0.0919 \\
\mathrm{P}(2 \mid 2)=0.9081\end{array}$ & $\begin{array}{l}\mathrm{P}(1 \mid 1)=0.9922 \\
\mathrm{P}(2 \mid 1)=0.0078\end{array}$ & $\begin{array}{l}\mathrm{P}(1 \mid 2)=0.0173 \\
\mathrm{P}(2 \mid 2)=0.9827\end{array}$ \\
\hline Exp. duration (Q) & 26.6969 & 10.8754 & 127.4635 & 57.8184 \\
\hline Log likelihood & \multicolumn{2}{|c|}{-103.2588} & \multicolumn{2}{|c|}{-20.6588} \\
\hline AIC & \multicolumn{2}{|c|}{2.2934} & \multicolumn{2}{|c|}{0.6789} \\
\hline $\mathrm{SC}$ & \multicolumn{2}{|c|}{2.7003} & \multicolumn{2}{|c|}{1.0762} \\
\hline HQC & \multicolumn{2}{|c|}{2.4583} & \multicolumn{2}{|c|}{0.8400} \\
\hline
\end{tabular}

Notes: The dependent variable is the primary deficit-to-GDP ratio. Standard errors in brackets. Q Quarters. AIC - Akaike information criterion. SC - Schwarz criterion. HQC - Hannan-Quinn criterion. $*, * *, * * *$, indicates statistical significance at a $10 \%, 5 \%$, and $1 \%$ level.

Source: Own calculations based on De Castro et al. (2014) and Paredes et al. (2014) databases.

\subsubsection{Cyclically-adjusted fiscal rule results}

In this subsection we present the outcomes related to the estimation of the "cyclicallyadjusted" fiscal rules based on equations (8) and (9). In contrast to those of the preceding subsection, these specifications are intended to assess the discretionary behavior of fiscal policymakers only.

\footnotetext{
${ }^{3}$ See Afonso and Toffano (2013) for estimation results of the Markov-Switching standard fiscal policy rules, with two regimes (constant transition probabilities), for the German, British, and Italian cases respectively. We should note that the specification of those fiscal rules is similar to that defined in equation (7), except for the lagged dependent variable, but database sources and sample periods are different. In an attempt to combine results from both papers, we can conclude that the German fiscal policymakers are the most concerned about debt stabilization because both regimes are "passive", although regime 2 is marginally less passive than regime 1 . The behavior of British fiscal policymakers is somehow between that of Germany and Italy and Spain, in the sense that it can be "passive" or "active" depending on the fiscal regime that prevails at every moment. The behavior of Italian and Spanish policymakers can be "passive" or neither active nor passive. The passive behavior of euro area countries is deemed to derive from European issues such as the need to comply with Maastricht criteria and the SGP rules, whereas British fiscal policymakers follow a different pattern.
} 
Table 4. Cyclically-adjusted fiscal policy rules for Spain

\begin{tabular}{|c|c|c|c|}
\hline & \multirow{2}{*}{$\begin{array}{c}\text { Fixed } \\
\text { fiscal rule }\end{array}$} & \multicolumn{2}{|c|}{ Markov-Switching fiscal rule } \\
\hline & & Regime 1 & Regime 2 \\
\hline Constant & $\begin{array}{c}0.0765 \\
(0.6638)\end{array}$ & $\begin{array}{c}0.6498 \\
(1.3599)\end{array}$ & $\begin{array}{l}-0.0513 \\
(0.5960)\end{array}$ \\
\hline Lagged (debt/GDP) & $\begin{array}{l}-0.0026 \\
(0.0105)\end{array}$ & $\begin{array}{l}-0.0043 \\
(0.0237)\end{array}$ & $\begin{array}{l}-0.0004 \\
(0.0082)\end{array}$ \\
\hline (expenditure/GDP) gap & $\begin{array}{c}0.7371 * * * \\
(0.1475)\end{array}$ & $\begin{array}{c}1.3237 * * * \\
(0.2933)\end{array}$ & $\begin{array}{l}0.2458 * * \\
(0.1238)\end{array}$ \\
\hline GDP gap & $\begin{array}{c}0.1000 \\
(0.0943) \\
\end{array}$ & $\begin{array}{c}0.1721 \\
(0.2022)\end{array}$ & $\begin{array}{l}-0.0794 \\
(0.0692)\end{array}$ \\
\hline Inflation rate & $\begin{array}{c}0.0067 \\
(0.0480)\end{array}$ & $\begin{array}{l}-0.0743 \\
(0.0944)\end{array}$ & $\begin{array}{c}0.0246 \\
(0.0421)\end{array}$ \\
\hline $\begin{array}{l}\text { Lagged cyclically- } \\
\text { adjusted (deficit/GDP) }\end{array}$ & $\begin{array}{c}0.5778 * * * \\
(0.0775)\end{array}$ & $\begin{array}{c}0.4477 * * * \\
(0.1316)\end{array}$ & $\begin{array}{c}0.5388 * * * \\
(0.0748) \\
\end{array}$ \\
\hline $\log ($ sigma $)$ & - & $\begin{array}{l}-0.0542 \\
(0.1247)\end{array}$ & $\begin{array}{c}-0.9582 * * * \\
(0.1151)\end{array}$ \\
\hline Transition probabilities & - & $\begin{array}{l}\mathrm{P}(1 \mid 1)=0.9313 \\
\mathrm{P}(2 \mid 1)=0.0687\end{array}$ & $\begin{array}{l}\mathrm{P}(1 \mid 2)=0.0649 \\
\mathrm{P}(2 \mid 2)=0.9351\end{array}$ \\
\hline Expected duration $(\mathrm{Q})$ & - & 14.5459 & 15.4077 \\
\hline Log likelihood & -124.8465 & & \\
\hline Akaike info criterion & 2.5163 & & \\
\hline Schwarz criterion & 2.6688 & & \\
\hline Hannan-Quinn criter. & 2.5781 & & \\
\hline
\end{tabular}

Notes: The dependent variable is the cyclically-adjusted primary deficit-to-GDP ratio. Standard errors in brackets. Q - Quarters. *,**,***, indicates statistical significance at a 10\%, 5\%, and 1\% level. Source: Own calculations based on De Castro et al. (2014) database.

The left side of Table 4 presents the Ordinary Least Squares estimation results for the fiscal rule described in equation (8) for the Spanish cyclically-adjusted primary deficit-to-GDP ratio. None of the coefficients is statistically significant, except the parameters associated to the primary expenditure gap and the lagged cyclically-adjusted primary deficit-to-GDP ratio. While the sign of the debt coefficient would be consistent with a "passive" fiscal policy, such effects are statistically non-significant. As we expected, the expenditure gap pushes up the primary deficit-to-GDP ratio. Moreover, fiscal policy is "acyclical", because the coefficient estimate on output gap is not statistically different from zero.

As in the case of non-cyclically adjusted variables, we can distinguish the existence of two regimes: regime 1, which basically prevails over the periods 1987:Q11990:Q3, 2002:Q2-2003:Q3, 2005:Q4-2009:Q3 and 2012:Q1-2012:Q4, and regime 2, which spans between 1990:Q4 and 2002:Q1, between 2003:Q4 and 2005:Q3, and between 2009:Q4 and 2011:Q4. Although both regimes can be defined as neither active nor passive and acyclical, the positive response of the primary deficit to a temporary surge in the government expenditure is higher in regime 1. We also depict the residual, actual and fitted cyclically-adjusted primary deficit-to-GDP ratio for Spain in Figure 4. From the inspection of that graph, we can conclude that our fiscal rule specified in equation (9) seems to fit the data rather well. 

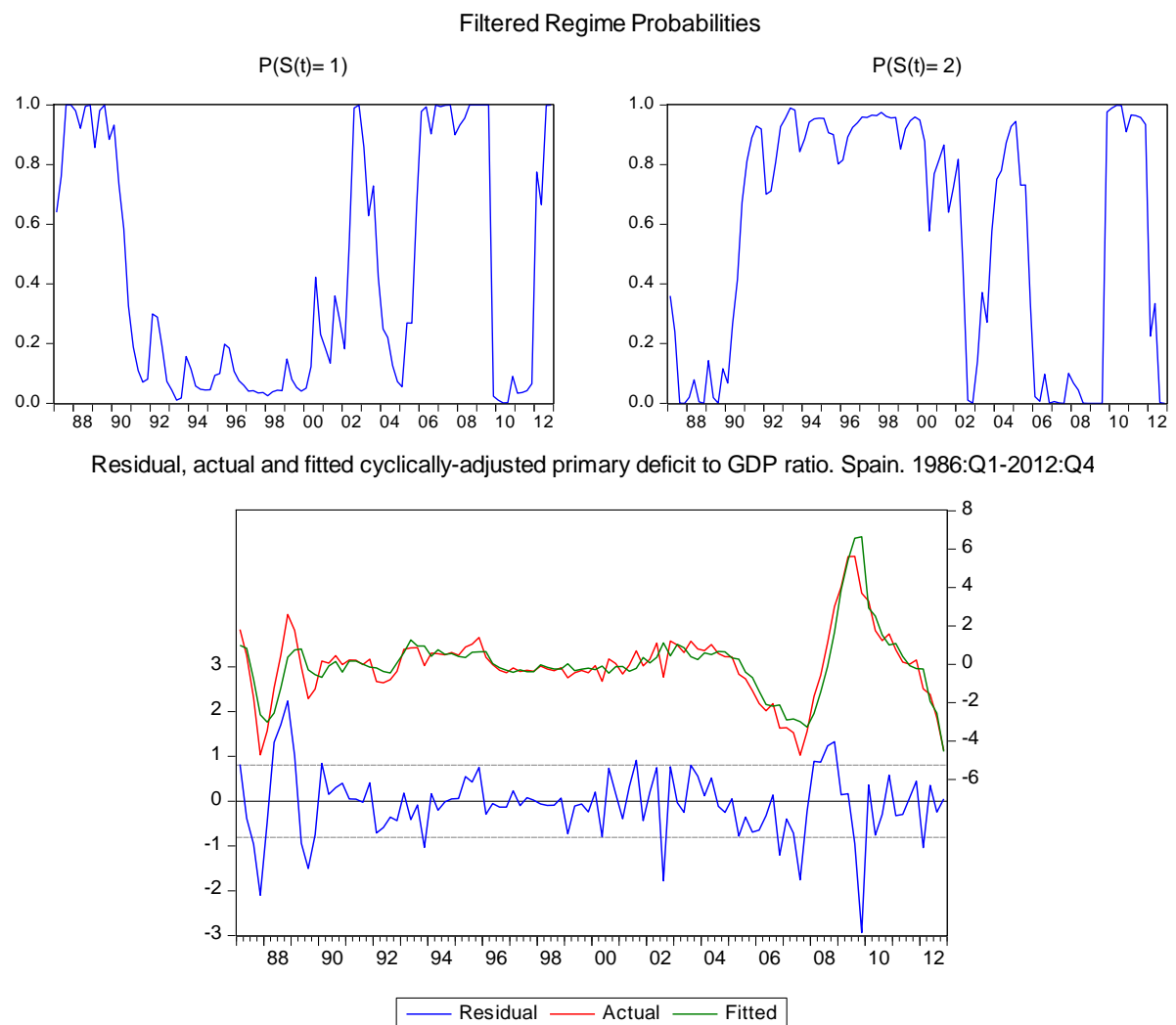

Figure 4. Fiscal regimes (constant transition probabilities). Spain. 1986:Q1-2012:Q4 Source: Own calculations based on De Castro et al. (2014) database.

Both regimes are very persistent as indicated by the transition probabilities presented at the bottom right of Table 4 . The probability that regime 1 is followed by regime 1 is 0.9313 , and the probability that regime 2 is followed by regime 2 is 0.9351 , so regime 2 is slightly more persistent than regime 1 . In addition, the expected duration of regime 1 is almost higher than that of regime 2; in particular, regime 1 would last for around 14.5 quarters, while the regime 2 would go on for about 15.4 quarters.

In the right side of Table 4, we report the Markov-Switching estimation results with two regimes (and constant transition probabilities) for the fiscal rule defined in equation (9). Almost none of the relevant coefficients are statistically significant, with the exception of the parameters related to the primary expenditure to GDP ratio gap and the lagged cyclically-adjusted primary deficit-to-GDP ratio in both regimes. Although past increases in the debt-to-GDP ratio are followed by a fall in the cyclically-adjusted primary deficit, suggesting that the behavior of fiscal policymakers could be regarded as "passive", such effects are statistically non-significant; hence fiscal policy can be once again considered as neither active nor passive in both regimes.

Furthermore, the coefficient on the output gap is positive in regime 1 and negative in regime 2, but in none of both regimes is the coefficient statistically significant, implying that fiscal policy can be regarded as "acyclical" vis-á-vis the business cycle as proxied by the output gap. However, the responses of the primary deficit-to-GDP ratio to primary expenditure gap developments are slightly different. In detail, although the expenditure gap pushes up the primary deficit in both regimes, this 
effect is stronger in regime 1. In turn, the Spanish fiscal stance is not affected by the evolution of the inflation rate. In both regimes, the coefficient estimate of the lagged primary deficit-to-GDP ratio is positive and significant, which suggests that this variable shows a high degree of persistence.

In short, according to the results of our Markov-Switching cyclically-adjusted fiscal rules, two fiscal regimes could be identified in Spain: regime 1, which ranges from the beginnings of 1987 to the third quarter of 1990, from the middle of 2003 to the third quarter of 2003, from the end of 2005 to the third quarter of 2009, and from 2012 onwards, and regime 2, which prevails in the rest of the sample. Both regimes are defined by a neither active nor passive and acyclical fiscal policy, except for the discretionary behavior of fiscal policymakers regarding to extraordinary expenditure, which is higher in regime $1 .^{4}$

Table 5. Markov-Switching cyclically-adjusted fiscal policy rules for Spain and the euro area

\begin{tabular}{|c|c|c|c|c|}
\hline & \multicolumn{2}{|c|}{ Spain (see Table 4) } & \multicolumn{2}{|c|}{ Euro area } \\
\hline & Regime 1 & Regime 2 & Regime 1 & Regime 2 \\
\hline Constant & $\begin{array}{c}0.6498 \\
(1.3599)\end{array}$ & $\begin{array}{l}-0.0513 \\
(0.5960)\end{array}$ & $\begin{array}{c}0.2282 \\
(0.5612)\end{array}$ & $\begin{array}{c}0.2176 \\
(0.7479)\end{array}$ \\
\hline $\begin{array}{l}\text { Lagged } \\
\text { (debt/GDP) }\end{array}$ & $\begin{array}{l}-0.0043 \\
(0.0237)\end{array}$ & $\begin{array}{l}-0.0004 \\
(0.0082)\end{array}$ & $\begin{array}{l}-0.0027 \\
(0.0066)\end{array}$ & $\begin{array}{l}-0.0051 \\
(0.0091)\end{array}$ \\
\hline $\begin{array}{l}\text { (expenditure/GDP } \\
\text { gap }\end{array}$ & $\begin{array}{c}1.3237 * * * \\
(0.2933)\end{array}$ & $\begin{array}{c}0.2458 * * \\
(0.1238)\end{array}$ & $\begin{array}{c}1.0292 * * * \\
(0.1008)\end{array}$ & $\begin{array}{l}0.2206 * * \\
(0.0907)\end{array}$ \\
\hline GDP gap & $\begin{array}{c}0.1721 \\
(0.2022)\end{array}$ & $\begin{array}{l}-0.0794 \\
(0.0692)\end{array}$ & $\begin{array}{l}0.1046 * * \\
(0.0520)\end{array}$ & $\begin{array}{l}-0.0742 \\
(0.0539)\end{array}$ \\
\hline Inflation rate & $\begin{array}{l}-0.0743 \\
(0.0944)\end{array}$ & $\begin{array}{c}0.0246 \\
(0.0421)\end{array}$ & $\begin{array}{c}0.0661 \\
(0.0475)\end{array}$ & $\begin{array}{c}0.0134 \\
(0.0530)\end{array}$ \\
\hline $\begin{array}{l}\text { Lagged cadj. } \\
\text { (deficit/GDP) }\end{array}$ & $\begin{array}{c}0.4477 * * * \\
(0.1316)\end{array}$ & $\begin{array}{c}0.5388 * * * \\
(0.0748)\end{array}$ & $\begin{array}{c}0.1706 * * * \\
(0.0559)\end{array}$ & $\begin{array}{c}0.6909 * * * \\
(0.0889)\end{array}$ \\
\hline $\log ($ sigma $)$ & $\begin{array}{l}-0.0542 \\
(0.1247) \\
\end{array}$ & $\begin{array}{c}-0.9582 * * * \\
(0.1151)\end{array}$ & $\begin{array}{c}-2.0214 * * * \\
(0.1597) \\
\end{array}$ & $\begin{array}{c}-1.2688 * * * \\
(0.0930)\end{array}$ \\
\hline $\begin{array}{l}\text { Transition } \\
\text { probabilities }\end{array}$ & $\begin{array}{l}\mathrm{P}(1 \mid 1)=0.9313 \\
\mathrm{P}(2 \mid 1)=0.0687\end{array}$ & $\begin{array}{l}\mathrm{P}(1 \mid 2)=0.0649 \\
\mathrm{P}(2 \mid 2)=0.9351\end{array}$ & $\begin{array}{l}\mathrm{P}(1 \mid 1)=0.8881 \\
\mathrm{P}(2 \mid 1)=0.1119\end{array}$ & $\begin{array}{l}\mathrm{P}(1 \mid 2)=0.0451 \\
\mathrm{P}(2 \mid 2)=0.9549\end{array}$ \\
\hline Exp. duration $(\mathrm{Q})$ & 14.5459 & 15.4077 & 8.9330 & 22.1502 \\
\hline Log likelihood & \multicolumn{2}{|c|}{-101.7174} & \multicolumn{2}{|c|}{-6.7690} \\
\hline AIC & \multicolumn{2}{|c|}{2.2638} & \multicolumn{2}{|c|}{0.4216} \\
\hline $\mathrm{SC}$ & \multicolumn{2}{|c|}{2.6706} & \multicolumn{2}{|c|}{0.8190} \\
\hline HQC & \multicolumn{2}{|c|}{2.4286} & \multicolumn{2}{|c|}{0.5828} \\
\hline
\end{tabular}

Notes: The dependent variable is the cyclically-adjusted primary deficit-to-GDP ratio. Standard errors in brackets. Q - Quarters. AIC - Akaike information criterion. SC - Schwarz criterion. HQC Hannan-Quinn criterion. *, **, ***, indicates statistical significance at a $10 \%, 5 \%$, and $1 \%$ level.

Source: Own calculations based on De Castro et al. (2014) and Paredes et al. (2014) databases.

For completeness, in Table 5 we present the combined estimation results of the Markov-Switching cyclically-adjusted fiscal policy rules, with two regimes (constant transition probabilities), specified in equation (9) for Spain and the euro area. From that table, we can also differentiate two regimes for the euro area: regime 1, which covers the mid-1990s, from the third quarter of 2001 to the first half of 2005, and from the

\footnotetext{
${ }^{4}$ Once again, we follow the recommendation of Diebold, Lee, and Weinbach (1994), and Filardo (1994), and therefore estimate the Markov-Switching two-regime fiscal policy rule denoted in equation (9), using variable-dependent transition probabilities for the case of Spain. The results are very close to those described in the main text for constant transition probabilities.
} 
third quarter of 2008 to the second quarter of 2012, and regime 2, which extends from the beginning of 1986 to the start of 1990, from the last quarter of 1990 to the first half of 2001, from the third quarter of 2005 to the first half of 2008, and from the third quarter of 2012 onwards. Both regimes can be described by a neither active nor passive fiscal policy; however, regime 1 is procyclical whereas regime 2 is acyclical, and extraordinary expenditure is higher in regime 1. Comparing these euro-area results with those of Spain explained above, the time paths of fiscal regimes in Spain and the euro area are partly synchronized, Spanish fiscal policymakers always behave in a neither active nor passive and acyclical way whereas euro-area fiscal policymakers sometimes act in a neither active nor passive but procyclical manner, and the responsiveness to extraordinary expenditure is somewhat higher in Spain (especially in regime 1).

\subsection{Markov-Switching VAR results}

In this section we present the outcomes related to the estimation of the MarkovSwitching VAR model specified in equation (10)..$^{5}$ Table 6 shows the transition probabilities and Figure 5 plots of the filtered probabilities of each regime. The probability that regime 1 is followed by regime 1 is 0.9919 , and the probability that regime 2 is followed by regime 2 is 0.9857 . As we can see from the graph, a regime shift at the third quarter of 1992 is detected.

Table 6. Constant Markov transition probabilities for the Markov-Switching VAR model with two regimes for Spain

\begin{tabular}{|c|c|c|}
\hline \multicolumn{3}{|c|}{$\begin{array}{l}\text { Constant transition probabilities } \\
\mathrm{P}(\mathrm{i}, \mathrm{k})=\mathrm{P}(\mathrm{s}(\mathrm{t})=\mathrm{k} \mid \mathrm{s}(\mathrm{t}-1)=\mathrm{i}) \\
(\mathrm{row}=\mathrm{i} / \text { column }=\mathrm{j})\end{array}$} \\
\hline & 1 & 2 \\
\hline 1 & 0.9919 & 0.0081 \\
\hline 2 & 0.0143 & 0.9857 \\
\hline
\end{tabular}

Source: Own calculations based on De Castro et al. (2014) database.

We aim to analyze the dynamic properties of the model by means of the Generalized Impulse Response Functions (GIRFs), which were proposed in Koop, Pesaran and Potter (1996) for nonlinear models and further developed in Ehrmann et al. (2003) for MS-VAR models. ${ }^{6}$ Specifically, we study the effects of a shock to the primary deficit-to-GDP ratio on the output gap for the Spanish economy.

The balance between the advantages and disadvantages of GIRFs makes them especially suitable for our analysis. On the one hand, GIRFs are invariant to the order of the variables in the VAR model. In particular, GIRFs do not require the orthogonalization of the residuals of the system and, therefore, any economic-based restrictions, since they take the historical correlations among the variables included in

\footnotetext{
5 The estimates of the Markov-Switching VAR model with 2 regimes (states) were obtained by Maximum Likelihood (ML). The Hamilton filtering algorithm was used to estimate the regimes. The numerical optimization to compute the ML estimates was based on the block-wise algorithm of Sims, Waggoner and Zha (2008).

${ }^{6}$ Because we are interested in comparing the impulse responses of diverse regimes, we need to compute "regime-dependent impulse responses" (Ehrmann et al., 2003), which are conditional on the regime prevailing at the time of the disturbance continuing to prevail throughout the duration of the responses.
} 
the estimated variance-covariance matrix. On the other hand, GIRFs do not provide information about the causal relationships among the variables. In this regard, the GIRFs do not require the identification of shocks, so that they cannot be used for economic policy simulations. Thus, it is impossible to interpret those economic shocks in a structural sense, with labels such as "supply shock", "demand shock" or "policy shock". In any case, the analysis of the effects of an unanticipated change in one of the observable variables on the other endogenous variables of the model is an essential step to be considered.

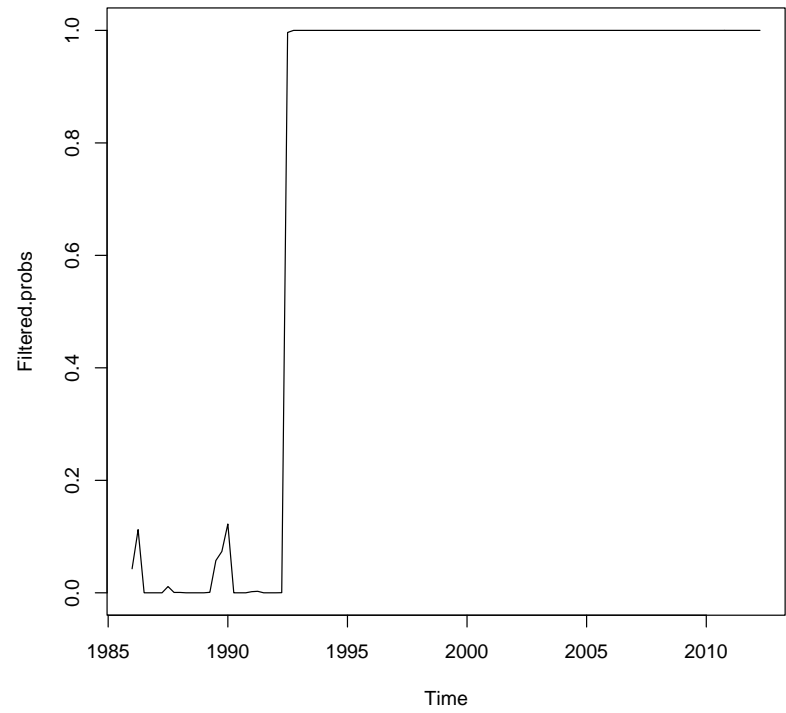

Figure 5. Fiscal regimes (constant transition probabilities) for Spain, 1986:Q1-2012:Q4 Source: Own calculations based on De Castro et al. (2014) database.

Below we present the effects of a positive shock to the primary deficit-to-GDP ratio on the output gap for the two main states (regimes 1 and 2 in Table 6 and Figure 5) that can be distinguished in the MS-VAR model build for Spain. Bearing in mind that the output gap normally grows in good economic times and decreases in bad times, the effect of the shock on the output gap can be characterized as follows. First, a positive reaction implies a Keynesian effect: deficit reduction harms growth. Conversely, a negative response unveils a non-Keynesian effect whereby a deficit reduction stimulates economic activity. In any other case, the fiscal shock has non-significant effects on economic activity.

Table 7. Generalized impulse responses of output gap to a 1 standard deviation cyclically-adjusted primary deficit-to-GDP ratio shock. Spain

\begin{tabular}{|c|c|c|c|c|}
\hline \multicolumn{1}{|c|}{ Quarters } & 1 & 4 & 8 & 12 \\
\hline \multirow{2}{*}{ Regime 1 } & -0.4050 & 0.0941 & 0.0300 & -0.0213 \\
& $(0.1762)$ & $(0.1600)$ & $(0.0577)$ & $(0.0371)$ \\
\hline \multirow{2}{*}{ Regime 2 } & -0.0322 & -0.2458 & -0.2751 & -0.1276 \\
& $(0.0453)$ & $(0.0605)$ & $(0.0909)$ & $(0.1178)$ \\
\hline
\end{tabular}

Notes: Responses in percentage terms. Standard errors in brackets.

Source: Own calculations based on De Castro et al. (2014) database. 
The generalized impulse responses of output gap to a (one standard deviation) positive shock to the cyclically-adjusted primary deficit-to-GDP ratio are displayed in Table 7 and Figure 6. In regime 1, which spans from the first quarter of 1986 to the second quarter of 1992, an unanticipated increase in the cyclically-adjusted primary deficit causes an instantaneous decrease of about 0.41 percent in the output of the country. In any case, output gap responses are not significant, for which regime 1 cannot be described as Keynesian.
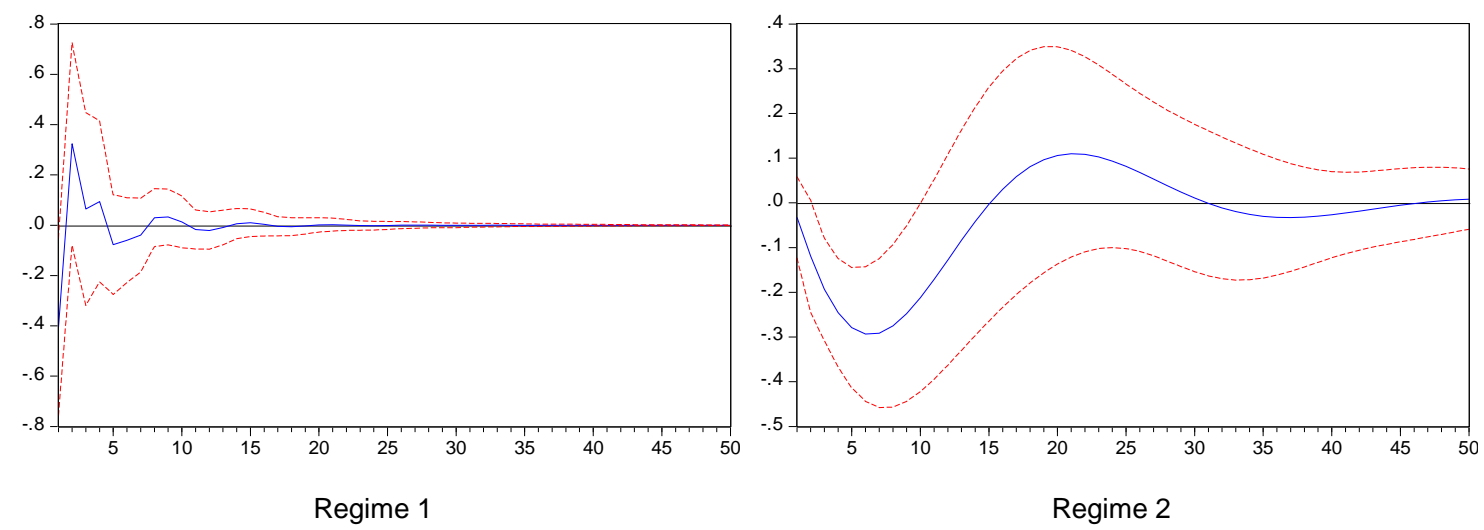

Figure 6. Generalized impulse responses of output gap to a 1 standard deviation cyclically-adjusted primary deficit-to-GDP ratio shock. Spain

Notes: Responses in percentage terms. Solid lines: baseline estimates, dashed lines: \pm 1 standard deviation confidence bands.

Source: Own calculations based on De Castro et al. (2014) database.

In regime 2, which spans from the third quarter of 1992 to the fourth quarter of 2012, the shock leads to a fall of the output gap between the second and the ninth quarters after the shock, reaching a minimum of 0.29 percent in the sixth quarter. As of the tenth quarter the effect of the shock on the output gap is diluted. In sum, from the results of our simulations, in regime 2 we observe a non-Keynesian effect during the first two and a half years and non-significant effects on activity thereafter.

\section{Conclusions}

In this paper we study fiscal regime shifts for the Spanish Economy, using a new quarterly dataset of Spanish public finance variables fit for economic analysis (see De Castro et al., 2014). In a first step, we characterize the behavior of Spanish fiscal policymakers by means of fiscal policy rules in which the government reacts to the public debt and the business cycle. Those fiscal reaction functions are not ad-hoc; rather, they are derived as optimal rules from an augmented New Keynesian structural model. In a second step, we estimate a vector autoregression model that includes macroeconomic, fiscal and financial variables and present the effects of an increase in the primary deficit-to-GDP. The VAR specification can be seen as an approximation to the conditional solution of an augmented New Keynesian structural model. In both steps, we apply Markov-Switching techniques to allow for a shift in the parameters of 
the fiscal policy rules and to account for the non-linearity of fiscal policy and its relation to different political preferences.

As expected by the analysis of previous literature, our results are very sensitive to the specification of the fiscal rule. Moreover, they can be conditioned by the inaccuracy of the HP filter we use to calculate the output gap at the beginning and the end of the sample. The results of the experiments carried out in our paper are summarized in Figure 7. In an attempt to combine the solutions of the standard and the cyclically-adjusted fiscal policy rules, we can conclude that Spanish fiscal policy tends to be acyclical throughout the analyzed period, but it is "passive" or neither active nor passive depending on the prevailing regime. To put in other words, some "automatic mechanism" embedded in the Spanish fiscal legislation tries to reduce the primary deficit-to-GDP ratio in response to past debt increases.

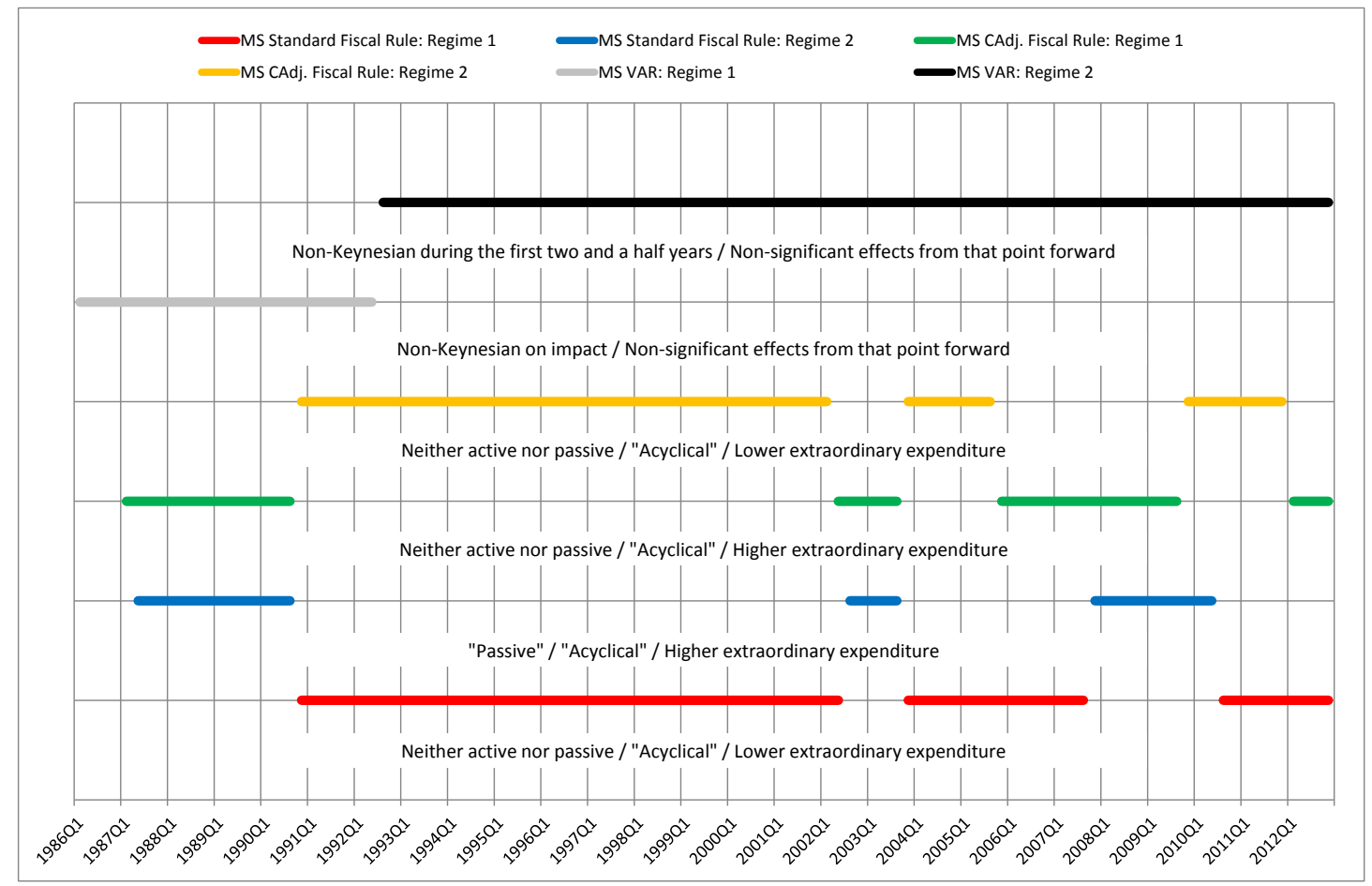

Figure 7. Behavior of Spanish fiscal policymakers based on Markov-Switching standard and cyclically-adjusted fiscal rules and a Markov-Switching VAR model. Spain. 1986:Q1-2012:Q4 Source: Own calculations based on De Castro et al. (2014) database.

More important, in order to assess the discretionary comportment of fiscal policymakers, we use cyclically-adjusted fiscal variables (i.e. we do not consider automatic stabilizers) to estimate both the MS cyclically-adjusted fiscal rule and the MS-VAR model. According to the results of our MS cyclically-adjusted fiscal rule, Spanish fiscal policymakers do not seem to track the state of public finances (as proxied by the public debt) and the evolution of economic activity (as proxied by the output gap) in both regimes that we identified, but they appear to focus on the level of extraordinary expenditure (as proxied by the primary expenditure gap), the responsiveness to which is higher in the first regime than in the second one. That extraordinary expenditure was connected to socioeconomic circumstances or political 
preferences, such as the Barcelona 1992 Summer Olympic Games and the Seville 1992 Universal Exposition (period 1987-1990), the early-2000s downturn and the Iraq War (period 2002-2003), and the social reforms under Zapatero's government and the late2000s Spanish economic and financial crisis (period 2005-2009). Conforming to the results of our MS-VAR model, increases in the primary deficit do not succeed in stimulating economic activity; rather, unexpected upsurges in the primary deficit-toGDP ratio harm economic activity (non-Keynesian effect) in the second regime, which prevails since the ratification of the Maastricht Treaty.

\section{References}

Afonso, A. (2008), "Ricardian Fiscal Regimes in the European Union", Empirica 35: 313-334.

Afonso, A., and P. Toffano (2013), "Fiscal Regimes in the EU”, European Central Bank Working Paper Series, No. 1529, April 2013.

Afonso, A., P. Claeys, and R. Sousa (2011), "Fiscal Regime Shifts in Portugal", Portuguese Economic Journal 10: 83-108.

Badinger, H. (2009), "Fiscal rules, discretionary fiscal policy and macroeconomic stability: an empirical assessment for OECD countries", Applied Economics 41: 829-847.

Ballabriga, F., and C. Martinez-Mongay (2005), "Sustainability of EU public finances," European Commission Economic Papers, No. 225, April 2005.

Barro, R. (1984), “The Behavior of U.S. Deficits”, NBER Working Papers 1309, National Bureau of Economic Research, Inc.

Beetsma, R., M. Giuliodori, and F Klaassen (2006), "Trade spill-overs of fiscal policy in the European Union: a panel analysis”, Economic Policy, October 2006, 639-687.

Blanchard, O.J., and R. Perotti (2002), "An empirical characterization of the dynamic effects of changes in government spending and taxes on output", Quarterly Journal of Economics 117 (4): 13291368.

Bohn, H. (1998), “The Behavior of U.S. Public Debt and Deficits”, Quarterly Journal of Economics 113: 949-963.

Bohn, H. (2005), "The Sustainability of Fiscal Policy in the United States”, CESifo Working Paper Series 1446.

Castañeda-Fernández, J.E. (2009), "Reglas fiscales activas: el caso de España”, Papeles de trabajo del Instituto de Estudios Fiscales. Serie economía, No. 4/09.

Claeys, P. (2004), "Monetary and Budgetary Policy Interaction: An SVAR Analysis of Stabilisation Policies in Monetary Union,” Economics Working Papers ECO2004/22, European University Institute.

Claeys, P. (2006), "Policy mix and debt sustainability: evidence from fiscal policy rules", Empirica 33: 89-112.

Claeys, P. (2008), "Rules, and their effects on fiscal policy”, Swedish Economic Policy Review 15: 7-48.

Clarida, R., J. Gali, and M. Gertler (1999), "The Science of Monetary Policy: A New Keynesian Perspective", Journal of Economic Literature 37: 1661-1707.

De Castro, F. (2006), “The macroeconomic effects of fiscal policy in Spain”, Applied Economics 38: 913924.

De Castro, F., F. Martí, A. Montesinos, J.J. Pérez, and A.J. Sánchez Fuentes (2014), "Fiscal policies in Spain: main stylized facts revisited”, Research Department, Banco de España, Documentos de Trabajo No 1408.

Diebold, F.X., J.H. Lee, and G. C. Weinbach (1994), "Regime Switching with Time-Varying Transition Probabilities," in C. Hargreaves (ed.), Nonstationary Time Series Analysis and Cointegration, Oxford: Oxford University Press, 283-302. 
Ehrmann, M., M. Ellison, and N. Valla (2003), "Regime-dependent impulse response functions in a Markov-switching vector autoregression model”, Economics Letters 78: 295-299.

Filardo, A.J. (1994), "Business-Cycle Phases and Their Transitional Dynamics", Journal of Business and Economic Statistics 12: 299-308.

Friedman, M. (1948), “A Monetary and Fiscal Framework for Economic Stability”, The American Economic Review 38: 245-264

Gali, J., and R. Perotti (2003), "Fiscal Policy and Monetary Integration in Europe", NBER Working Papers 9773, National Bureau of Economic Research, Inc.

Golinelli, R., and S. Momigliano (2008), "The cyclical response of fiscal policies in the euro area. Why do results of empirical research differ so strongly?", Banca d'Italia Temi di Discussione, No. 652, January 2008.

Hamilton J.D. (1990), "Analysis of time series subject to changes in regime", Journal of Econometrics 45: $39-70$.

Hamilton, J.D. (1989), "A New Approach to the Economic Analysis of Nonstationary Time Series and the Business Cycle", Econometrica 57(2): 357-84.

Kim, C.J., and C.R. Nelson (1999), State-Space Models with Regime Switching, Cambridge, Massachusetts: MIT Press.

Kirsanova, T., S. Stehn, and D. Vines (2006), "Five-Equation Macroeconomics: A Simple view of the Interactions between Fiscal Policy and Monetary Policy”, CEPR Discussion Paper 5464.

Koop, G., M.H. Pesaran, and S.M. Potter (1996), "Impulse Response Analysis in Nonlinear Multivariate Models", Journal of Econometrics 74: 119-147.

Krolzig, H.-M. (1997), Markov Switching Vector Autoregressions. Modelling, Statistical Inference and Application to Business Cycle Analysis, Berlin: Springer.

Leeper, E. (1991), 'Equilibria under 'active' and 'passive' monetary and fiscal policies", Journal of Monetary Economics 27: 129-147.

Marneffe, W., B. van Aarle, W. van der Wielen, and L. Vereeck (2011), "The Impact of Fiscal Rules on Public Finances in the Euro Area”, CESifo DICE Report Journal for Institutional Comparisons 9, 18-25.

Paredes, J., D.J. Pedregal, and J.J. Pérez (2014), "Fiscal policy analysis in the euro area: Expanding the toolkit", Journal of Policy Modeling, http://dx.doi.org/10.1016/j.jpolmod.2014.07.003.

Perotti, R. (2005), "Estimating the effects of fiscal policy in OECD countries", CEPR Discussion Paper, No. 4842.

Pesaran, M.H., and Y. Shin (1998), “Generalized Impulse Response Analysis in Linear Multivariate Models”, Economics Letters 58: 17-29.

Reade, J.J. (2011), "Modelling Monetary and Fiscal Policy in the US: A Cointegration Approach", University of Birmingham Department of Economics Discussion Paper 11-02.

Sims, C.A., D.F. Waggoner, and T. Zha (2008), "Methods for inference in large multiple-equation Markov-switching models", Journal of Econometrics 146: 255-274.

Svensson, L.E.O. (1999), "Inflation Targeting As a Monetary Policy Rule", Journal of Monetary Economics 43: 607-654.

Taylor, J.B. (1993), “Discretion versus Policy Rules in Practice”, Carnegie-Rochester Conference Series on Public Policy 39: 195-214.

Thams, A. (2007), "Fiscal Policy Rules in Practice", mimeo. 